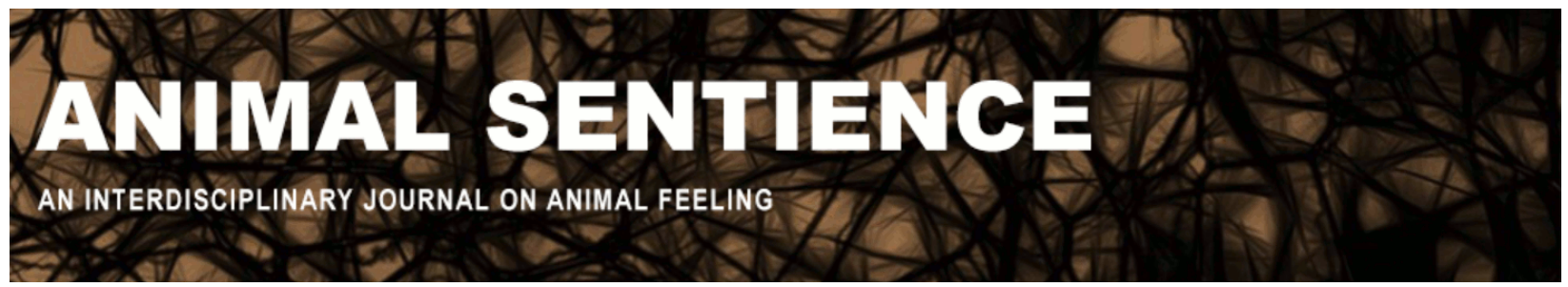

Jacquet, Jennifer; Franks, Becca; and Godfrey-Smith, Peter (2019) The octopus mind and the argument against farming it. Animal Sentience 26(19)

DOI: $10.51291 / 2377-7478.1504$

Date of submission: 2019-07-09

Date of acceptance: 2019-07-22

(c) 


\title{
The octopus mind and the argument against farming it
}

Commentary on Mather on Octopus Mind

\author{
Jennifer Jacquet \\ Department of Environmental Studies \\ New York University \\ Becca Franks \\ Department of Environmental Studies \\ New York University \\ Peter Godfrey-Smith \\ Faculty of Science \\ University of Sydney
}

\begin{abstract}
Mather is convincing about octopuses having 'a controlling mind, motivated to gather information,' but stops short of asking what having that mind means for octopus moral standing. One consequence of understanding the octopus mind should be a refusal to subject octopuses to mass production. Octopus farming is in an experimental phase and supported by various countries. We argue that it is unethical because of concerns about animal welfare as well as environmental impacts.
\end{abstract}

\begin{abstract}
Jennifer Jacquet, assistant professor in the Department of Environmental Studies at New York University and part of NYU Animal Studies, works on large-scale environmental problems, including overfishing, climate change, and the Internet wildlife trade. Website
\end{abstract}

Becca Franks, visiting assistant professor in the Department of Environmental Studies at New York University, studies well-being and motivation, with a focus on aquatic animal welfare. Website

Peter Godfrey-Smith is Professor of History and Philosophy of Science at University of Sydney. His main research interests are philosophy of biology and philosophy of mind. His books include Other Minds: The Octopus, the Sea, and the Deep Origins of Consciousness. Website
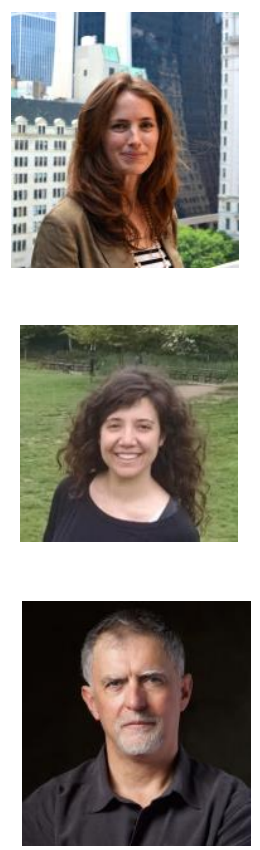

Mather (2019a) presents ample evidence that octopuses have personalities, causal reasoning, get bored, and have imaginations. These are features we humans understand. She also describes unique aspects of octopuses' 'way of being' - such as a nervous system distributed 
mostly throughout eight arms and the ability to camouflage themselves using chromatophores. Mather also argues convincingly that octopuses have 'a controlling mind, motivated to gather information.' Yet she stops short of asking what possessing that mind means for octopus moral standing (see commentaries of Browning 2019 and King \& Marino 2019).

One consequence of understanding the octopus mind should be a refusal to subject octopuses to mass production. This is in an experimental phase today and supported by various countries, including Spain, Mexico, China, and Japan. Octopus farming is unethical because of concerns about animal welfare as well as environmental impact (Jacquet et al., 2019).

Mass production of octopus would mean controlled, sterile, and monotonous environments (probably experienced in isolation) combined with set diets and regimented feeding schedules, all designed to maximize biomass, not wellbeing. Few studies have considered octopus welfare in farmed settings (for an overview see Castanheira, 2019), but these have reported high rates of cannibalism and aggression at higher stocking densities (Pham \& Isidro, 2009), parasitic infections (Ladineo \& Ozić, 2005), and problems with digestion (Sykes et al., 2017). Intensive farm systems are inevitably hostile to the positive experiences octopuses are likely to seek, including high levels of cognitive stimulation (Mather \& Dickel, 2017), opportunities to explore, manipulate, and control their environment (Finn et al., 2009; Levy et al., 2015; Steer \& Semmens, 2003), and social interaction (Boal, 2006; Caldwell et al., 2015; Scheel et al., 2017).

Beyond welfare concerns, commercial octopus farming would also be ecologically unsustainable. Octopuses are carnivores and require protein from other animals in their diet. Octopuses in captivity grow best on a diet consisting primarily of crab, but diets of mackerel (Pham \& Isidro, 2009) or squid and hake have also been tried (Cerezo Valverde \& García García, 2016). Rather than alleviating pressure on wild aquatic animals, farming octopus would increase pressure. As with any captive carnivore, farming octopus is inefficient: it would feed people but the result would be a net loss of animal protein.

Ecologists have emphasized that farming carnivores is unsustainable (e.g., Ackefors \& Rosén, 1979; Naylor et al., 2000). Aquaculture is a valuable and probably inevitable part of the future of human food consumption, but it can be implemented more or less responsibly. From a sustainability perspective, farming should not focus on carnivores but on organisms lower on the food chain that we do not need to feed, such as mussels and oysters (Jacquet et al., 2017), seaweeds, and other options. Owing to concerns about environmental impact as well as human health, experts have argued that human diets should be composed predominantly or exclusively of plants (Willett, 2019). Although the argument that 'people have to eat' has been used to justify the development of octopus farming (including by Mather, 2019b) the human diet need not include farmed octopus. Unlike the octopus, humans have immensely flexible diets.

The nascent octopus farming industry has also argued that octopus farming will meet global demand for octopus. However, as with aquaculture in general, which has not been a substitute for capture fisheries but has added to the global supply of seafood (e.g., Longo et al., 2019), octopus farming would probably result in creating demand for octopus.

The octopus industry has also said octopus farming will create jobs. Any new enterprise, including going to war or building prisons, is likely to create jobs. The question is at what cost. Farming oysters, seaweed, or lentils would also create jobs without subjecting 'a controlling mind' to mass production. We must ultimately ask ourselves whether farming the octopus - an 
undomesticated, sentient, and sophisticated carnivore - is the right thing to do. We believe it is not. The following scholars (signing as individuals, not on behalf of their institutions) agree:

\section{Signatures}

1. ABRAMS Peter, University of Toronto, Canada

2. AINLEY David, Marine Ecologist, USA

3. AL-ABDULRAZZAK Dalal, Vericatch, Canada

4. ALAVA Juan Jose, Institute for the Oceans and Fisheries, University of British Columbia, Canada, \& Fundacion Ecuatoriana para el Estudio de Mamiferos Marinos (FEMM), Ecuador

5. ARECHAVALA-LOPEZ Pablo, Mediterranean Institute of Advanced Studies, Spain

6. ATHANASSAKIS Yanoula, New York University, USA

7. BAKER Liv, Hunter College, USA

8. BEKOFF Marc, University of Colorado, USA

9. BERGHMANS Federico, University of Buenos Aires, Argentina

10. BERGSTROM Carl, Department of Biology, University of Washington, USA

11. BOLGER Niall, Columbia University, USA

12. BROAD Kenneth, University of Miami, USA

13. BROOKS Cassandra, University of Colorado Boulder, USA

14. BROTZ Lucas, Institute for the Oceans and Fisheries, University of British Columbia, Canada

15. BROWNING Heather, Australian National University, Australia

16. CASAL Paula, Catalan Institution for Research and Advanced Studies, Spain

17. CARRETERO-GONZÁLEZ Margarita, Universidad de Granada, Spain

18. CHAUDHURI Una, New York University, USA

19. CLARK Stephen R.L., University of Liverpool (Professor Emeritus), UK

20. CONLEY Dalton, Princeton University, USA

21. CRAMER Katie, Scripps Institution of Oceanography, USA

22. DAVIES Ben, University of Oxford, UK

23. DELON Nicolas, New College of Florida, USA

24. DENNETT Daniel, Tufts University, USA

25. DONALDSON Brianne, Rice University, USA

26. DOYLE Rebecca, University of Melbourne, Australia

27. ESTES James, University of California, Santa Cruz, USA

28. FENTON Andrew, Dalhousie University, Canada

29. FISCHER Bob, Texas State University, USA

30. FONSECA Rui, Centro de Investigação e Estudos de Sociologia (CIES-IUL), Portugal

31. FRASER David, Animal Welfare Program, University of British Columbia, Canada

32. FROESE Rainer, GEOMAR Helmholtz Centre for Ocean Research, Germany

33. GAGLIANO Monica, University of Sydney, Australia

34. GLASER Sarah, One Earth Future, USA

35. GRUEN Lori, William Griffin Professor of Philosophy, Wesleyan University, USA

36. GUPTA Kristin, Rice University, USA

37. HALTEMAN Matthew C., Calvin College, USA

38. HAYEK Matthew, Harvard University, USA

39. HERRMANN Kathrin, Johns Hopkins Bloomberg School of Public Health, USA

40. HIGGINS E. Tory, Columbia University, USA

41. HINTZE Sara, University of Natural Resources and Life Sciences Vienna BOKU, Austria

42. HOROWITZ Alexandra, Barnard College, USA 
43. ILEA Ramona, Professor of Philosophy, Pacific University Oregon, USA

44. JACKSON Jeremy B.C., Scripps Institution of Oceanography, USA

45. JAMIESON Dale, Department of Environmental Studies, New York University, USA

46. JEROLMACK Colin, New York University, USA

47. JOHN Tyler M., Philosophy, Rutgers University-New Brunswick, USA

48. JOHNS Brandon, California State University - San Bernardino, USA

49. JOHNSON Ayana, Ocean Collectiv, USA

50. JOHNSON Syd, Michigan Technological University, USA

51. JOST John T., New York University, USA

52. KILLOREN David, Australian Catholic University, Australia

53. KING Barbara J., College of William and Mary, USA

54. KNEBA Elliot, Veterinarian, England

55. KRISTENSEN Bjørn, University of Oregon, USA

56. LERNER Adam, New York University Center for Bioethics, USA

57. MAKOWSKA Joanna, University of British Columbia, Canada

58. MARINO Lori, Kimmela Center for Animal Advocacy, USA

59. MCCAULEY Douglas, University of California Santa Barbara, USA

60. MCCLENACHAN Loren, Colby College, USA

61. MCDERMID Sonali, New York University, USA

62. MELOTTI Luca, University of Münster, Germany

63. MIGUENS Sofia, University of Porto, Portugal

64. MILINSKI Manfred, Max-Planck-Institute for Evolutionary Biology, Plön, Germany

65. MULÀ Anna, Foundation Franz Weber, Spain

66. NAGY Kelsi, Colorado State University, USA

67. NOTARBARTOLO DI SCIARA Giuseppe, Tethys Research Institute, Milano, Italy

68. ORMANDY Elisabeth, Animals in Science Policy Institute, Canada

69. OVEN Alice, University of Winchester, UK

70. PAEZ Eze, University of Minho, Portugal \& UPF-Centre for Animal Ethics, Spain

71. PALOMARES Deng, Institute of Oceans and Fisheries, University of British Columbia, Canada

72. PARDALOU Androniki, School of Biology, Aristotle University of Thessaloniki, Greece

73. PAULY Daniel, University of British Columbia, Canada

74. PENG Guo, Philosophy Department, Shandong University, China

75. PICKETT Susana, University of Leicester, UK

76. POLICARPO Verónica, Instituto de Ciéncias Sociais (ICS), Universidade de Lisboa, Portugal

77. PROUDFOOT Kathryn, Ohio State University, USA

78. PULEO Alicia, Philosophy Department of the Universidad de Valladolid, Spain

79. RADER Priscilla, Animal League Defense Fund, USA

80. RAJAN Kanaka, Princeton University, USA

81. REISS Diana, Hunter College, USA

82. RIESER Alison, University of Hawaii, USA

83. ROBERTS Callum, University of York, UK

84. RYAN Erin, British Columbia Animal Welfare Program, Canada

85. SAFINA Carl, Stony Brook University, USA

86. SALA Enric, National Geographic Society, USA

87. SARAIVA Joao L., Fish Ethology and Welfare Group, CCMAR, Portugal

88. SCHANZ Lisa, University of Natural Resources and Life Sciences (BOKU) Vienna, Austria

89. SCHENKENFELDER Josef, University of Natural Resources and Life Sciences Vienna, Austria

90. SCHLOTTMANN Christopher, Department of Environmental Studies, NYU, USA 
91. SEBO Jeff, New York University, USA

92. SHRIVER Adam, Oxford Uehrio Centre for Practical Ethics, UK

93. SINGER Peter, Princeton University, USA

94. SMUTS Barbara, Psychology, University of Michigan (Professor Emeritus), USA

95. SOMMERS Tamler, Philosophy, University of Houston, USA

96. SUDER Billo Heinzpeter, President, Guarantor Fish Ethology and Welfare Group, Germany

97. TAFALLA Marta, Philosophy Department, Universitat Autònoma de Barcelona, Spain

98. TAVELLA Elizabeth, University of Chicago, USA

99. THIYAGARAJAN Nandini, New York University, USA

100. TSIKLIRAS Athanassios, Aristotle University of Thessaloniki, Greece

101. TUMINELLO Joseph, McNeese State University, USA

102. VENTURA Beth, University of Minnesota, USA

103. VOLSTORF Jenny, Fish Ethology and Welfare Group, Germany

104. VOLTES Adrià, Antropologia de la Vida Animal (Institut Català d'Antropologia), Spain

105. WATLING Les, University of Hawaii, USA

106. WEBB Christine, Department of Human Evolutionary Biology, Harvard University, USA

107. WINCKLER Christoph, University Natural Resources \& Life Sciences Vienna, Austria

108. WINTER Drew, Rice University, USA

109. ZAVITZ Tayler, University of Victoria, Canada

110. ZOLLITSCH Werner, University of Natural Resources and Life Sciences Vienna, Austria

111. ZOZAYA Stephen, James Cook University, Australia

\section{References}

Ackefors, H., \& Rosén, C.G. (1979). Farming aquatic animals: the emergence of a world-wide industry with profound ecological consequences. $A M B I O, 8,132-143$.

Boal, J.G. (2006). Social Regognition: a top down view of cephalopod behavior. Vie et MilieuLife and Environment, 56(2), 69-79.

Browning, H. (2019). What is good for an octopus?. Animal Sentience 26(7).

Caldwell, R.L., Ross, R., Rodaniche, A., \& Huffard, C.L. (2015). Behavior and body patterns of the Larger Pacific Striped Octopus. PLoS ONE, 10(8), 1-17.

Castanheira, M.F. (2019). Octopus vulgaris. In: FishEthoBase, ed. Fish Ethology and Welfare Group.

Cerezo Valverde, J., \& García García, B. (2017). High feeding and growth rates in common octopus (Octopus vulgaris) fed formulated feeds with an improved amino acid profile and mixture of binders. Aquaculture Research, 48(7), 3308-3319.

Finn, J.K., Tregenza, T., \& Norman, M.D. (2009). Defensive tool use in a coconut-carrying octopus. Current Biology, 19, 1069-1070.

Jacquet, J., Franks, B., Godfrey-Smith, P., \& Sanchez-Suarez, W. (2019). The case against octopus farming. Issues in Science and Technology, 35(2), 37-44.

Jacquet, J., Sebo, J., \& Elder, M. (2017). Seafood in the future: Bivalves are better. Solutions, 8, 27-32.

King, B.J., \& Marino, L. (2019). Octopus minds must lead to octopus ethics. Animal Sentience 26(14).

Ladineo, I.M., \& Ozić, M.J. (2005). Aggregata infection in the common octopus, Octopus vulgaris, 
Cephalopoda: Octopodidae, reared in a flow-through system. Area, 46, 193-199.

Longo, S.B., Clark, B., York, R., \& Jorgenson, A.K. (2019). Aquaculture and the displacement of capture fisheries. Conservation Biology, 33(4), 832-841.

Mather, J. (2019a). What is in an octopus's mind? Animal Sentience 26(1).

Mather, J. (2019b). Octopus farming (response). Issues in Science and Technology, 35(3).

Mather, J.A., \& Dickel, L. (2017). Cephalopod complex cognition. Current Opinion in Behavioral Sciences, 16, 131-137.

Naylor, R.L., Goldburg, R.J., Primavera, J.H., Kautsky, N., Beveridge, M.C.M., Clay, J., Folke, C., Lubchenco, J., Mooney, H., \& Troell, M. (2000). Effect of aquaculture on world fish supplies. Nature, 405, 1017-1024.

Pham, C.K., \& Isidro, E. (2009). Growth and mortality of common octopus (Octopus vulgaris) fed a monospecific fish diet. Journal of Shellfish Research, 28, 617-623.

Scheel, D., Chancellor, S., Hing, M., Lawrence, M., Linquist, S., \& Godfrey-Smith, P. (2017). A second site occupied by Octopustetricus at high densities, with notes on their ecology and behavior. Marine and Freshwater Behaviour and Physiology, 50, 285-291.

Sykes, A.V., Almansa, E., Cooke, G.M., Ponte, G., \& Andrews, P.L.R. (2017). The digestive tract of cephalopods: A neglected topic of relevance to animal welfare in the laboratory and aquaculture. Frontiers in Physiology, 8, 1-16.

Willett, W., Rockström, J., Loken, B., Springmann, M., Lang, T., Vermeulen, S., \& Garnett, T. (2019). Food in the anthropocene: The EAT-Lancet Commission on Healthy Diets from Sustainable Food Systems. The Lancet, 393, 447-492. 